\title{
sciendo
}

DOI 10.2478/sbe-2020-0055

SBE no. 15(3) 2020

\section{THE IMPACT OF CLIMATE CHANGE ON INCOME INEQUALITY. EVIDENCE FROM EUROPEAN UNION COUNTRIES}

\author{
ALBU ADA-CRISTINA \\ Institute for World Economy, Romanian Academy, Romania \\ ALBU LUCIAN-LIVIU \\ Institute for Economic Forecasting, Romanian Academy, Romania
}

\begin{abstract}
:
We will investigate in this paper the relation between income inequality and climate change, taking into account that the increase of carbon emissions has among consequences the increase of inequalities. The most vulnerable to climate change are the poorest and less developed countries. Climate change represents an important challenge for EU policymakers and the transition to zerocarbon emissions will lead to greater social inclusion and convergence among EU countries. We use in this paper two-stage OLS in order to analyse the relationship between income inequality and carbon emissions in case of EU countries. We apply our model to two groups of European Union countries, the old member states - EU15 and new member states - EU13. Our results confirm that there are important differences between the two groups regarding the relationship between climate change and income inequalities. Therefore, policies implemented at EU level are extremely important in order to mitigate the adverse effects of climate change on growing inequality and poverty in EU countries. Governments must invest in new technologies, industries and innovation in order to address the complex challenge posed by mitigating climate change.
\end{abstract}

Key words: income inequality, poverty, climate change mitigation policies

\section{Introduction}

The nexus income inequality-climate change has a special importance, taking into account the necessity to take urgent action in order to decrease the level of carbon emissions, which will produce long lasting effects from the social and economic perspective for European Union countries. Climate change actions and mitigation policies represent a priority for policymakers, due to the deep impacts and also the unprecedented pace of environmental degradation. Finding the optimum threshold between climate change and preserving economic growth requires an in-depth analysis of economic growth sources and also finding the right balance between carbon emissions and economic development. 
The relation between income inequality, economic growth and environmental degradation can be investigated from several perspectives. Economic growth is usually related to an increase in carbon emissions due to industrial development and economic organization. At the same time, income inequality can contribute to an increase of $\mathrm{CO} 2$ emissions, as poor people and countries have fewer possibilities and incentives to comply with climate change requirements and use clean energy. At the same time, there is extensive empirical evidence that countries with a low-income inequality have also lower carbon emissions, which should encourage the proposal of actions in order to decrease Gini coefficients as a modality to realise the transition to a green economy.

Climate change actions will affect especially the poorest regions and countries of the European Union, which are not well prepared to cope with this challenge of transition to clean energy and zero-carbon emissions (European Environment Agency, 2017). Therefore, Eastern and Southern European countries have to modernize the industries based on coal and help the workforce from the polluting sectors and industries to relocate to other jobs. In this way, investments will be needed in order to prevent the rise in income inequality and social negative impacts due to climate change actions.

Climate change can affect more severely the regions which have poor financial ability to adapt to the changes caused by the climate degradation. Taking into account the large amount of resources necessary to cope with the negative effects of extreme weather events, the less well-off persons and regions will be less prepared to adapt to this change. Moreover, the process of transition to a green economy and implementation of effective climate change mitigation actions requires extensive financing, which poor countries, regions or individuals do not possess.

The Environmental Kuznets Curve (EKC) hypothesis shows that the relation between income inequality and environmental protection is more pronounced in case of low levels of income inequality and poor regions, while when countries and individuals become richer, environmental degradation becomes lower (figure 1). The explanation resides in the fact that higher income creates propensity to consume better climate environment and better environmental quality.

At the beginning of economic development, environmental degradation is higher and continues a descending trend depending on economic growth evolution, the relation between environmental pollution and Gini index manifesting as an inverted U-shaped curve relation (Kuznets, 1995).

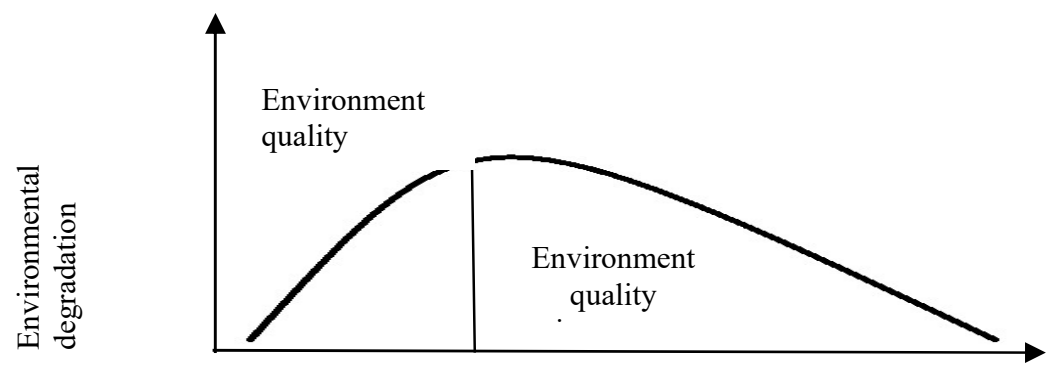

GDP per capita

Figure 1. Environmental Kuznets curve 
In European Union, especially Eastern European countries still have industries which are coal-dependent, and which will consequently bear the consequences of this industrial transformation in a disproportionate manner, especially considering the lack of financial resources to support the process of transition.

The impact on the job market from the transition to zero-carbon emissions will be disappearance of traditional jobs, combined with creation of new jobs in different sectors of the economy, created as a result of the new economic organization, based on clean energy and green economy. The sectors which are prone to undergone through significant changes are especially the transport sector, agriculture and services, which will be transformed in order to comply with the new climate change requirements.

Due to different economic structures and degrees of development, different policies and actions are necessary in European Union in order to address the complex challenge of industrial transformation in accordance with climate change requirements. There are several countries in which industries will face an excessive burden due to the dependency on carbon-intensive energy sources.

Investment in climate change and a comprehensive strategy for the transition to zero-carbon economy represent priorities for European Union policies in order to keep under control the increase of global temperatures, which will produce far-reaching economic consequences on the lives and economies of European countries. Thus, European Union authorities have proposed several strategies and comprehensive policies in order to decrease the negative impacts of increasing carbon emissions.

The transition to zero-carbon emissions by 2050, the target proposed by European Union in order to decrease negative externalities associated with environmental degradation, will require extensive financing in order to promote investment in energy efficiency, in ensuring cleaner sources of energy as well as lower-carbon transport. Besides investment in R\&D related to climate change, European Union industries will require massive transformation in order to comply with environmental targets.

Economy activity as it is organized today is unsustainable due to an extensive utilization of resources and also because increase of production was accompanied by an increase in carbon emissions, between 2000-2012, CO2 emissions having increased by 33 percent worldwide. This resource and carbon-intensive model of economic activity has produced environmental degradation with an unprecedented speed in the last years (International Labour Organization, 2018).

\section{Literature review}

The relation between income inequality and climate change has been studied extensively, taking into account the importance of this topic for ensuring a sustainable economic growth in European Union countries. The evidence on the climate changeincome inequality nexus is mixed, taking into account that it is difficult to establish a certain threshold beyond which carbon emissions increase affects income inequality.

According to several authors, higher income inequality is associated with a decrease in carbon emissions (Heerink et al., 2001; Boyce, 2007; Guo, 2014). There are 
also studies presenting a positive relation between income inequality and carbon emissions (Drabo, 2011; Knight et al., 2017).

The relation between economic growth, income inequality and carbon emissions depends also on the fact whether income distribution is preferred by low-income groups to environmental protection. Usually, low-income groups and countries are interested in economic growth and not in climate mitigation policies, while high incomes are usually associated with a preference for environmental protection (Scruggs, 1998).

Another classical study on this topic (Boyce, 1994) states that environmental degradation can worsen depending on income inequality in two important respects. First, the balance of power between winners and losers in environmental degradation can contribute to worsening of this relation depending on which side has the strongest position (if winners are still in power, then environmental pollution deteriorates further). Second, in case income inequality becomes greater, then this will increase the rate of time preference for both rich and poor, which will result in further environmental deterioration.

Other studies investigate the nexus income inequality-carbon emissions taking into account the marginal propensity to emit. Higher income inequality can contribute to better environmental quality due to the marginal propensity to emit (Ravallion et al., 2000; Heerink et al., 2001). Using a pooled OLS model for 42 countries during 1975-1992, the paper of Ravallion et al. (2000) finds the existence of a trade-off between reduction of $\mathrm{CO} 2$ emissions and inequality decline. Heerink et al. (2001) find a negative correlation between income inequality and carbon emissions using panel datasets for 65 countries.

Regarding the impact of climate change on the welfare of a state, there are authors showing that increase of $\mathrm{CO} 2$ emissions has contributed to the reduction of welfare (Donadelli et al., 2017). A research made at the level of EU countries shows the important role played by incomes in the carbon footprint of a certain region (Ivanova et al., 2017).

\section{Methodology}

We have chosen for our analysis two-stage OLS in order to analyse the relation between income inequality and carbon emissions in European Union countries, dividing EU countries in two groups, old EU member states (EU15) and new member states (EU13). We have followed the method proposed by Jeong Hwan Bae (2018), employing in the first stage an equation for analysing the relation between economic growth and income inequality. In the second stage of the regression, we have used the measure for estimated economic growth from the first equation in order to study the impact of carbon emissions on Gini index in the two groups of EU countries. We have used the Gini coefficient as a measure for income inequality and income per capita in PPS as a measure for economic growth.

We have presented our results for the two main groups of European Union separately, in order to investigate which are the main differences between the group of more developed European Union countries, EU-15 and the group of new member states, EU-13. 
New member countries, especially the Eastern group, perform worse regarding climate change indicators and environmental protection as well as the Gini coefficient measuring income inequality. The reasons for this performance are twofold: first, these countries do not possess a long history of compliance with environmental regulations, and they still utilize polluting industries on a large scale. Environmental targets are not fulfilled in these countries and the process of convergence towards more developed European states still needs transition in order to reach a higher level of environmental protection.

For our analysis we have used the following variables, extracted mainly from Eurostat and AMECO databases, as well as from World Development Indicators, International Monetary Fund:

Real GDP per capita, measured in euro per capita, source Eurostat

- $\quad$ Gini coefficient of equivalised disposable income, measured on a scale from 0 to 100, extracted from Eurostat database

- $\quad$ Crude rate of total population change, source Eurostat

- $\quad$ Net returns on net capital stock, index 2015=100, source AMECO database

- Inflation, consumer prices, measured in \%, database World Development Indicators, International Monetary Fund

- Market performance of exports of goods and services on export weighted imports of goods and services, unit $2015=100$, source AMECO

- $\quad$ Total expenditure of general government, percentage of GDP at current prices, source AMECO

- $\quad$ Greenhouse gas emissions per capita, annual data, source Eurostat

- Industrial production, index 2015=100, source Eurostat

- $\quad$ Exports of goods and services, in \% of GDP, source Eurostat

- $\quad$ Energy efficiency, index 2005=100, source Eurostat

- $\quad$ Share of fuels in final energy consumption, percentage, source Eurostat.

In the first regression, we have used as determinants of GDP growth the following variables: income inequality, population change, the net return on net capital stock, inflation rate, performance of exports and public expenditure as a percentage of GDP. It is expected that the growth rate of population, the return on capital, export performance and public expenditure are positively corelated with economic growth. A square and linear term of the Gini coefficient was included in the econometric model to test if an inverted $U$ shaped relationship exists between GDP and income inequality.

\section{$G D P_{i t}=\alpha+\alpha_{1} G I N I_{i t}+\alpha_{2} G I N I_{i t}^{2}+\alpha_{3} P_{o p} c h_{i t}+\alpha_{4} R_{e t} c a p_{i t}+\alpha_{5} I N F L_{i t}+$ $\alpha_{6} E X P_{-} P E R F_{i t}+\sigma_{7} E X P E N D_{i t}+\varepsilon_{i t}$}

For the second regression, we have chosen carbon emissions as the dependent variable and as explicative variables the estimated GDP per capita from the first regression, income inequality measured by Gini index, industrial production, exports in percentage of GDP, energy efficiency and share of fuels in total energy consumption. We expect that GDP growth rate, industrial production, exports and share of fuels in energy consumption to be positively correlated with carbon emissions, while energy efficiency should be negatively related to the dependent variable. 


\section{$C O 2_{i t}=\beta_{1}+\beta_{2} G D P E_{i t}+\beta_{3} G D P E_{i t}^{2}+\beta_{4} I N D_{-} P R O D_{i t}+\beta_{5} E X P_{i t}+\beta_{i s} E E F_{i t}+\beta_{7} f_{u s l s}+$ $\beta_{\mathrm{g}} G I N I_{\text {it }}+u_{\text {it }}$}

We have added in both equations the square term of income inequality and respectively estimated GDP, in order to verify the existence of an inverted U-shape relationship between our main variables studied, taking into account the possibility that these relations are not linear.

\section{Results}

The group represented by EU15 countries, respectively the group of developed EU countries, has on average higher income per capita, lower income inequality and less carbon emissions per capita compared with EU13, the group of less developed EU countries. We can also note that a decrease of GINI index is associated with a decrease of environmental degradation (figures 2).
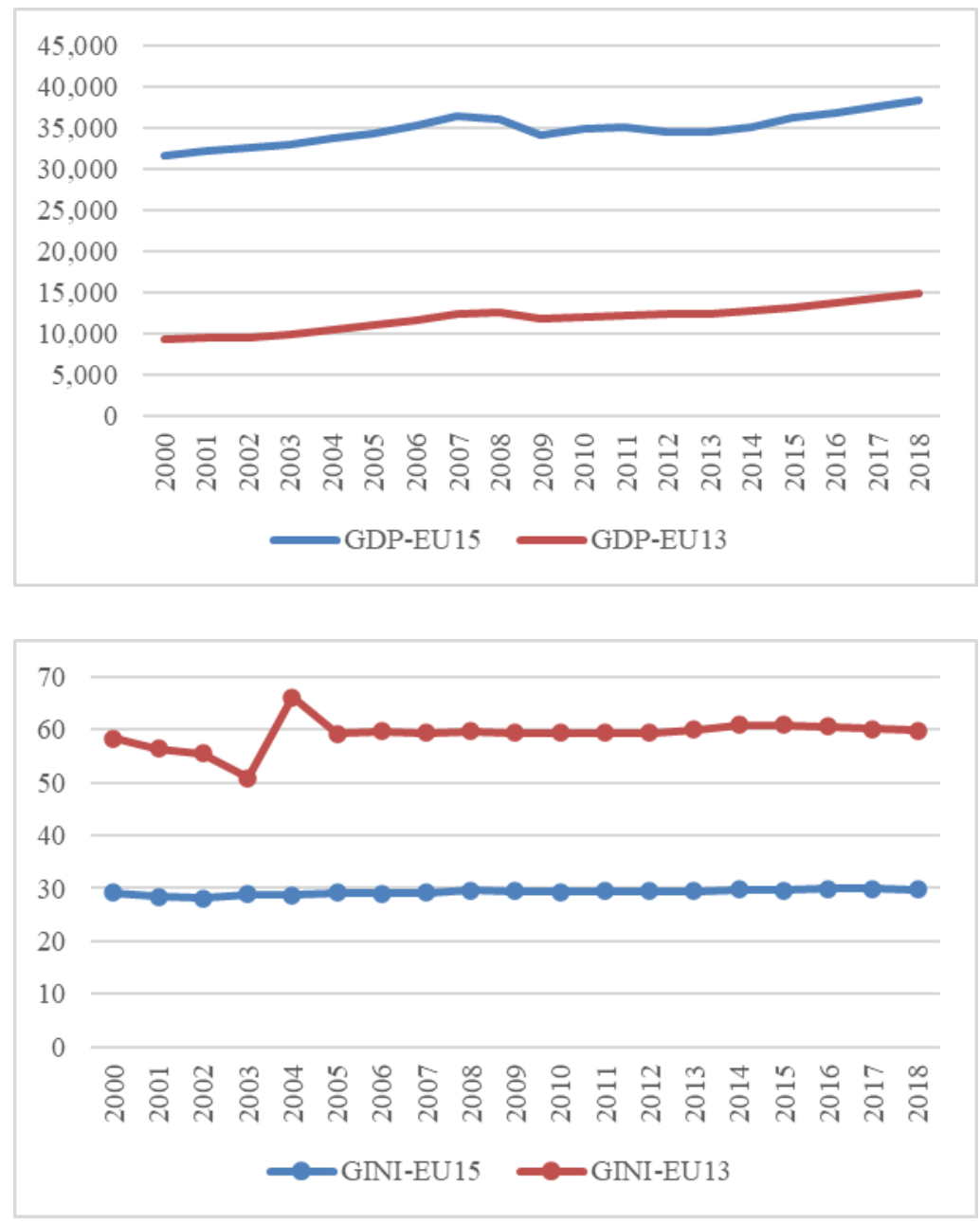


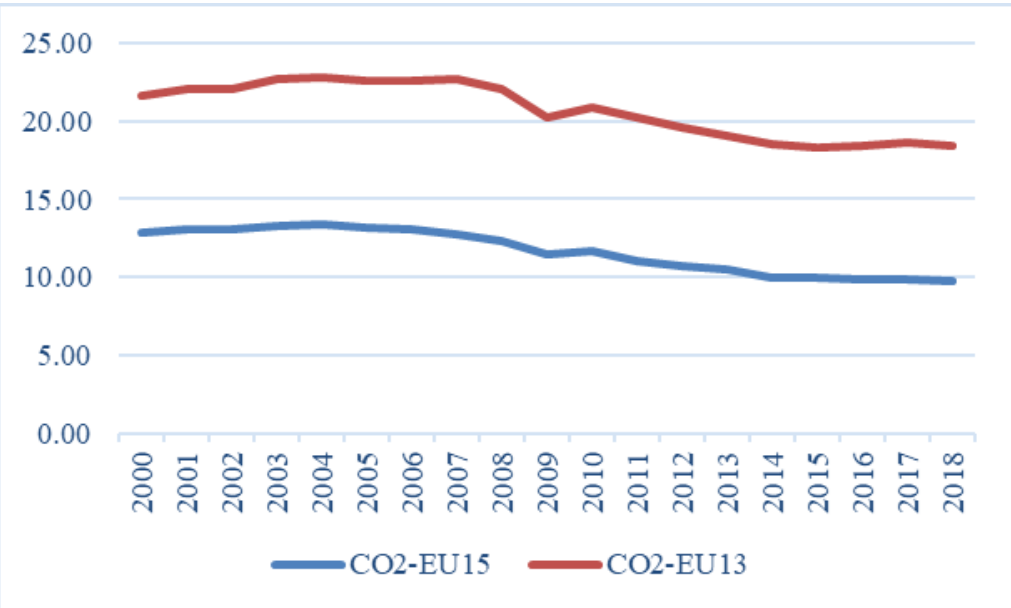

Figure 2. GDP per capita, GINI index, CO2 emissions per capita in EU15 and EU13, 2000-2018

Source: Elaborated by the authors using Eurostat database

The explanation resides in the fact that rich countries have more resources to invest in clean energy and technologies in order to modernize industrial production in line with climate change requirements. These countries have more money to finance R\&D for sustainable energy sources and promotion of clean energy in all technologies is more developed. At the same time, these countries move polluting industries usually to developing countries, due to a higher interest in ensuring a good-quality climate environment, being more preoccupied with environmental safety and well-being.

We have performed our two-stage OLS estimations as follows: for the Equation 1, we made the fixed-effects regressions with country-dummy variables for the group of EU15 and for the group of EU13 countries. We have calculated two estimations, one with country-dummy variables, to take into account country heterogeneities, which represent an important issue for panel data regressions, and also fixed-effects estimation without country specific effects.

In case of the group EU15, our results show that all coefficients are statistically significant. There is a positive relation between GDP per capita and Gini coefficient, an increase of 1 percent of income inequality index producing an increase by 1.89 percentage points of the variable GDP per capita. The rate of population change, return on capital and performance of exports are positively associated with economic growth ratio. There is a negative relation between inflation rate and governmental expenditure and the rate of GDP growth. The square term of Gini coefficient is negatively related to GDP, which shows that there is a non-linear relation between inequality and economic growth.

For the second regression equation estimated for EU15, we have calculated the impact of the explanatory variables on carbon emissions. There is a negative relation between Gini index and carbon emissions, an increase of Gini coefficient by 1 percent resulting in the decrease of carbon emissions by 0.25 percentage points. We also find a negative relation between industrial production and carbon emissions and between exports as share of GDP and CO2. The other variables, the estimated GDP per capita from the first equation, energy efficiency and fuels share in total fuels are positive related with 
carbon emissions, an increase of these variables resulting in an increase of $\mathrm{CO} 2$. We also find the existence of a non-linear relationship between GDP per capita and CO2 emissions, confirming thus the Kuznets environmental curve, according to which there is a turning point in the evolution of pollution and economic development (table 1).

\section{Table 1. Fixed effects regressions, estimated on panel data for EU15, during 2000-} 2018

\begin{tabular}{|c|c|c|c|c|c|}
\hline $\begin{array}{l}\text { EU15 } \\
\text { Equation } 1\end{array}$ & $\begin{array}{l}\text { Fixed-effects } \\
\text { (within) regression } \\
\text { with country-dummy } \\
\text { variables }\end{array}$ & $\begin{array}{l}\text { Fixed-effects } \\
\text { (within) } \\
\text { regression }\end{array}$ & $\begin{array}{l}\text { EU15 } \\
\text { Equation } 1\end{array}$ & $\begin{array}{l}\text { Fixed-effects } \\
\text { (within) regression } \\
\text { with country- } \\
\text { dummy variables }\end{array}$ & $\begin{array}{l}\text { Fixed-effects } \\
\text { (within) } \\
\text { - regression }\end{array}$ \\
\hline \multirow[t]{2}{*}{ gini } & $1,98^{* *}$ & $1,98^{* *}$ & country_5 & $-4,64^{* * *}$ & \\
\hline & (859.2) & (859.2) & & $(812.4)$ & \\
\hline \multirow[t]{2}{*}{ gini2 } & $-27.81^{*}$ & $-27.81^{*}$ & country_6 & $-2,69^{* * *}$ & \\
\hline & $(14.70)$ & $(14.7)$ & & (872.2) & \\
\hline \multirow[t]{2}{*}{ pop_change } & $131.3^{* \star *}$ & $131.3^{\star \star *}$ & country_7 & $-17,77^{\star \star \star}$ & \\
\hline & $(38.57)$ & $(38.57)$ & & $(1,05)$ & \\
\hline \multirow[t]{2}{*}{ ret_capital } & 8.01 & 8.01 & country_8 & $4,83^{* * *}$ & \\
\hline & $(19.14)$ & (19.14) & & $(1,40)$ & \\
\hline \multirow[t]{2}{*}{ inflation } & $-426.9^{\star \star *}$ & $-426.9^{\star \star *}$ & country_9 & $-10,46^{\star * *}$ & \\
\hline & $(119.0)$ & $(119.0)$ & & $(917.9)$ & \\
\hline \multirow[t]{2}{*}{ perf_exports } & $101.2^{* * *}$ & $101.2^{* * *}$ & country_10 & $41,94^{* * *}$ & \\
\hline & $(20.96)$ & (20.96) & & $(1,04)$ & \\
\hline \multirow[t]{2}{*}{ expend_gov } & $-108.9^{* *}$ & $-108.9^{* *}$ & country_11 & $3,22^{* * *}$ & \\
\hline & $(52.85)$ & $(52.85)$ & & $(853.0)$ & \\
\hline \multirow[t]{2}{*}{ country_2 } & $-2,20^{* * *}$ & $-4,86$ & country_12 & $-18,78^{\star * *}$ & \\
\hline & $(738.1)$ & $(12,58)$ & country_13 & $-14,62^{* * *}$ & \\
\hline \multirow[t]{2}{*}{ country_3 } & $10,58^{* * *}$ & & & $(1,03)$ & \\
\hline & $(758.7)$ & & country_14 & $5,07^{\star * *}$ & \\
\hline \multirow[t]{7}{*}{ country_4 } & $-1,37^{*}$ & & & $(782.7)$ & \\
\hline & $(779.4)$ & & country_15 & $-7,99^{* * *}$ & \\
\hline & & & & $(1,06)$ & \\
\hline & & & Constant & $-3,87$ & \\
\hline & & & & $(12,65)$ & \\
\hline & & & Observations & 285 & 285 \\
\hline & & & R-squared & 0.97 & 0.31 \\
\hline \multicolumn{6}{|c|}{ Standard errors in parentheses, ${ }^{* * *} p<0.01,{ }^{* *} p<0.05,{ }^{*} p<0.1$} \\
\hline $\begin{array}{l}\text { EU15 } \\
\text { Equation } 2\end{array}$ & $\begin{array}{l}\text { Fixed-effects } \\
\text { (within) } \\
\text { regression }\end{array}$ & $\begin{array}{l}\text { ixed-effects (within) } \\
\text { gression with } \\
\text { ountry-dummy } \\
\text { ariables }\end{array}$ & $\begin{array}{l}\text { EU15 } \\
\text { Equation } 2\end{array}$ & $\begin{array}{l}\text { Fixed-effects } \\
\text { (within) } \\
\text { regression }\end{array}$ & $\begin{array}{l}\text { ixed-effects (within) } \\
\text { egression with } \\
\text { ountry-dummy } \\
\text { ariables }\end{array}$ \\
\hline \multirow[t]{2}{*}{ GDP_predict } & $0.003^{* * *}$ & $0.003^{\star \star \star}$ & country_5 & & $-2.60^{* \star *}$ \\
\hline & $(0.001)$ & $(0.001)$ & & & $(0.39)$ \\
\hline GDP_predict2 & $-4.24^{* * *}$ & $-4.24^{* * *}$ & country_6 & & $1.30^{* * *}$ \\
\hline
\end{tabular}




\begin{tabular}{|c|c|c|c|c|c|}
\hline & $(1.47)$ & $(1.47)$ & & & $(0.31)$ \\
\hline \multirow[t]{2}{*}{ gini } & $-0.25^{\star \star \star}$ & $-0.25^{\star \star \star}$ & country_7 & & $1.70^{\star \star \star}$ \\
\hline & $(0.04)$ & $(0.04)$ & & & $(0.56)$ \\
\hline \multirow[t]{2}{*}{ indprod } & $-0.01^{* *}$ & $-0.01^{* *}$ & country_8 & & $8.25^{\star \star \star}$ \\
\hline & $(0.006)$ & $(0.006)$ & & & $(0.58)$ \\
\hline \multirow[t]{2}{*}{ exports } & $-0.07^{\star \star \star}$ & $-0.07^{\star \star *}$ & country_9 & & -0.33 \\
\hline & $(0.007)$ & $(0.007)$ & & & $(0.53)$ \\
\hline \multirow[t]{2}{*}{ energyeffic } & $0.16^{\star \star \star}$ & $0.16^{\star \star *}$ & country_10 & & $25.69^{\star \star \star}$ \\
\hline & $(0.01)$ & $(0.01)$ & & & $(1.00)$ \\
\hline \multirow[t]{2}{*}{ fuelsshare } & $0.58^{\star \star *}$ & $0.58^{\star \star \star}$ & country_11 & & $5.42^{\star \star *}$ \\
\hline & $(0.12)$ & $(0.12)$ & & & $(0.34)$ \\
\hline \multirow[t]{2}{*}{ country_2 } & & $4.19^{\star \star \star}$ & country_12 & & -0.33 \\
\hline & & $(0.35)$ & & & $(0.58)$ \\
\hline \multirow[t]{2}{*}{ country_3 } & & $1.81^{\star \star \star}$ & country_13 & & -0.16 \\
\hline & & $(0.30)$ & & & $(0.54)$ \\
\hline \multirow[t]{8}{*}{ country_4 } & & $1.88^{* * *}$ & country_14 & & $-3.50^{* \star *}$ \\
\hline & & $(0.34)$ & & & $(0.31)$ \\
\hline & & & country_15 & & 0.59 \\
\hline & & & & & $(0.51)$ \\
\hline & & & Constant & $-48.66^{* * *}$ & $-51.59^{\star \star \star}$ \\
\hline & & & & $(17.83)$ & (17.89) \\
\hline & & & Observations & 285 & 285 \\
\hline & & & R-squared & 0.73 & 0.96 \\
\hline
\end{tabular}

Source: Author's calculations.

For the case of the group of countries EU13, we estimate in the first equation the effects of the Gini coefficient and other explanatory variables on the economic growth ratio. Our findings confirm that there is a non-linear relation between GDP per capita and Gini coefficient. An increase of income inequality by 1 percentage point will result in the decrease of GDP by 0.38 percentage points. The variables rate of population change and governmental expenditure are positively related with economic growth rate, while there is a negative relation between net return on net capital stock, inflation rate and performance of exports with GDP growth.

We also estimate a second stage regression equation, for the relation between carbon emissions and GDP per capita. There is a positive relation between $\mathrm{CO} 2$ emissions and Gini coefficient in case of EU13 countries, thus an increase by $1 \%$ of income inequality will have as result an increase by 0.03 of carbon emissions. Exports as \% of GDP are negatively related with $\mathrm{CO} 2$, while there is a positive relation between carbon emissions and industrial production, energy efficiency and fuels share. An increase of these variables will also result in an increase of $\mathrm{CO} 2$ emissions (table 2). 
Table 2. Fixed effects regressions, estimated on panel data for EU13, during 2000-2018

\begin{tabular}{|c|c|c|c|c|c|}
\hline $\begin{array}{l}\text { EU13 } \\
\text { Equation } 1\end{array}$ & $\begin{array}{l}\text { Fixed-effects } \\
\text { (within) } \\
\text { regression }\end{array}$ & $\begin{array}{l}\text { Fixed-effects } \\
\text { (within) } \\
\text { regression with } \\
\text { country-dummy } \\
\text { variables }\end{array}$ & $\begin{array}{l}\text { EU13 } \\
\text { Equation } 1\end{array}$ & $\begin{array}{l}\text { Fixed-effects } \\
\text { (within) } \\
\text { regression }\end{array}$ & $\begin{array}{l}\text { Fixed-effects } \\
\text { (within) } \\
\text { regression wit } \\
\text { country-dummy } \\
\text { variables }\end{array}$ \\
\hline \multirow[t]{2}{*}{ gini } & $-38.25^{\star *}$ & $-38.25^{\star *}$ & country_5 & & $-69.63^{* * *}$ \\
\hline & (18.52) & (18.52) & & & (20.08) \\
\hline \multirow[t]{2}{*}{ gini2 } & $0.63^{\star \star}$ & $0.63^{\star *}$ & country_6 & & $-85.26^{\star * *}$ \\
\hline & $(0.29)$ & $(0.29)$ & & & $(28.06)$ \\
\hline \multirow[t]{2}{*}{ pop_change } & 1.15 & 1.15 & country_7 & & $-35.52^{*}$ \\
\hline & $(0.73)$ & $(0.73)$ & & & $(20.77)$ \\
\hline \multirow[t]{2}{*}{ ret_capital } & -0.24 & -0.24 & country_8 & & -23.28 \\
\hline & $(0.29)$ & $(0.29)$ & & & (21.91) \\
\hline \multirow[t]{2}{*}{ inflation } & -0.61 & -0.61 & country_9 & & $-93.50^{* * *}$ \\
\hline & $(1.15)$ & $(1.15)$ & & & $(29.27)$ \\
\hline \multirow[t]{2}{*}{ perf_exports } & $-1.24^{* * *}$ & $-1.24^{\star \star \star}$ & country_10 & & -28.96 \\
\hline & $(0.29)$ & $(0.29)$ & & & $(23.96)$ \\
\hline \multirow[t]{2}{*}{ expend_gov } & $2.64^{*}$ & $2.64^{*}$ & country_11 & & 8.69 \\
\hline & (1.57) & $(1.57)$ & & & $(24.14)$ \\
\hline \multirow[t]{2}{*}{ country_2 } & & $-92.97^{\star \star *}$ & country_12 & & $-84.02^{\star * *}$ \\
\hline & & $(26.56)$ & & & $(29.83)$ \\
\hline \multirow[t]{2}{*}{ country_3 } & & -34.24 & country_13 & & $-96.23^{\star \star *}$ \\
\hline & & $(25.72)$ & & & $(34.50)$ \\
\hline \multirow[t]{4}{*}{ country_4 } & & $-107.6^{\star * \star}$ & Constant & $700.7^{* *}$ & $757.8^{* *}$ \\
\hline & & $(27.96)$ & & $(305.0)$ & $(307.5)$ \\
\hline & & & Observations & 247 & 247 \\
\hline & & & R-squared & 0.13 & 0.31 \\
\hline
\end{tabular}

Standard errors in parentheses, ${ }^{* * *} p<0.01,{ }^{* *} p<0.05,{ }^{*} p<0.1$

\begin{tabular}{|c|c|c|c|c|c|}
\hline $\begin{array}{l}\text { EU13 } \\
\text { Equation } 2\end{array}$ & $\begin{array}{l}\text { Fixed-effects } \\
\text { (within) } \\
\text { regression }\end{array}$ & $\begin{array}{l}\text { Fixed-effects } \\
\text { (within) } \\
\text { regression with } \\
\text { country-dummy } \\
\text { variables }\end{array}$ & & $\begin{array}{l}\text { Fixed-effects } \\
\text { (within) } \\
\text { regression }\end{array}$ & $\begin{array}{l}\text { Fixed-effects } \\
\text { (within) } \\
\text { regression with } \\
\text { country-dummy } \\
\text { variables }\end{array}$ \\
\hline \multirow[t]{2}{*}{ gdp1_predict } & 0.002 & 0.002 & country_5 & & $7.38^{* * *}$ \\
\hline & (0.009) & (0.009) & & & $(0.35)$ \\
\hline \multirow[t]{2}{*}{ gdp1_predict2 } & 9.00 & 9.00 & country_6 & & 0.46 \\
\hline & (3.14) & $(3.14)$ & & & $(0.32)$ \\
\hline \multirow[t]{2}{*}{ gini } & $0.03^{*}$ & $0.033^{*}$ & country_7 & & $-2.30^{\star \star *}$ \\
\hline & $(0.02)$ & $(0.02)$ & & & $(0.27)$ \\
\hline \multirow[t]{2}{*}{ indprod } & $0.02^{* * *}$ & $0.02^{* * *}$ & country_8 & & -0.26 \\
\hline & $(0.004)$ & $(0.004)$ & & & $(0.23)$ \\
\hline \multirow[t]{2}{*}{ exports } & $-0.02^{* * *}$ & $-0.02^{* * *}$ & country_9 & & -0.03 \\
\hline & $(0.006)$ & $(0.006)$ & & & $(0.54)$ \\
\hline \multirow[t]{2}{*}{ energyeffic } & $0.05^{\star * \star}$ & $0.05^{\star * *}$ & country_10 & & -0.13 \\
\hline & $(0.006)$ & $(0.006)$ & & & $(0.42)$ \\
\hline fuelsshare & $0.15^{\star * *}$ & $0.15^{\star \star *}$ & country_11 & & $-1.72^{\star \star \star}$ \\
\hline
\end{tabular}


(0.02)

country_2

country_3

country_4
(0.02)

$-1.33^{\star * *}$

$4.10^{* \star *}$

$5.58^{* * *}$

(0.33) country_12

country_13

Constant

0.58

(1.2)

246

Observations

R-squared

0.48
(0.26)

$1.84^{* * *}$

$2.56^{* * *}$

$-0.65$

246

0.95

Standard errors in parentheses, ${ }^{* * *} p<0.01,{ }^{* *} p<0.05,{ }^{*} p<0.1$

Source: Author's calculations.

We can notice that the two groups of countries, EU15 and EU13, have different regression results regarding the relation between GDP per capita, income inequality and carbon emissions. Thus, we can conclude that the two groups of European Union countries have very different patterns of behaviour regarding the effect of income inequality on the level of carbon emissions. Because income inequality depends on the level of GDP per capita, this explains the different behaviours for the two groups of countries. The group of countries with a higher GDP per capita has less income inequality and lower CO2, while the group of countries with a lower GDP per capita has higher Gini coefficients and also higher emissions per capita. We present in the next figure the non-linear relations between income inequality and GDP per capita, and between carbon emissions and Gini index, for the two groups of countries separately, in order to evidence the different patterns for the evolution of the relation GDP-income inequality-CO2 (figure 3 and 4).
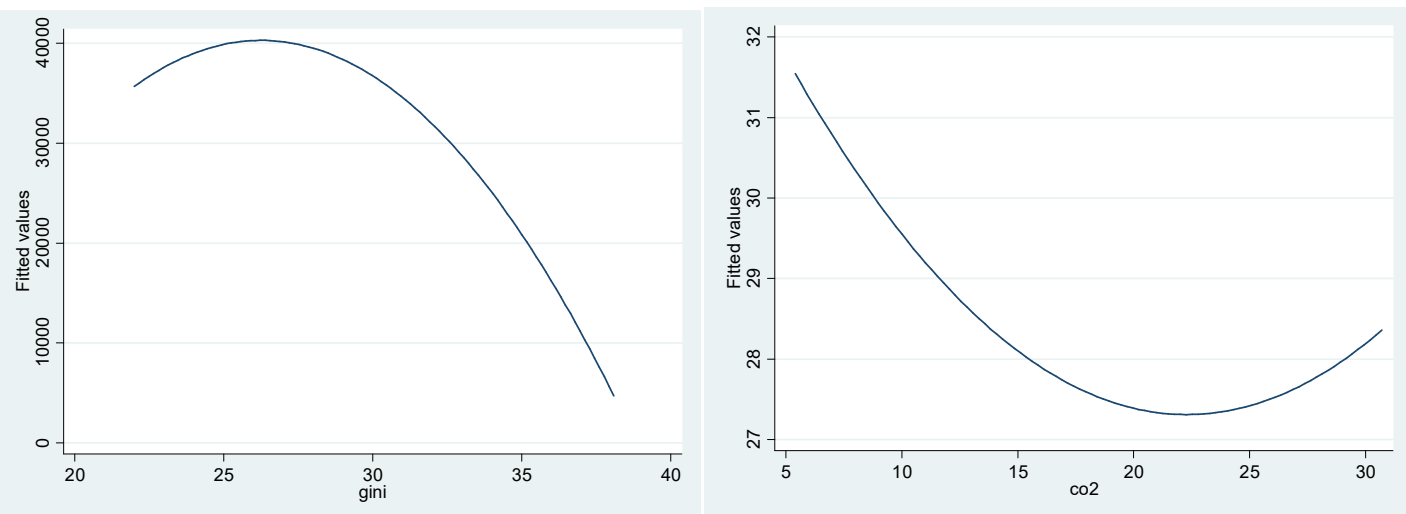

Figure 3. Estimates for relation Gini-GDP per capita (left figure), CO2-Gini (right figure) for EU15

Source: Author's calculations. 

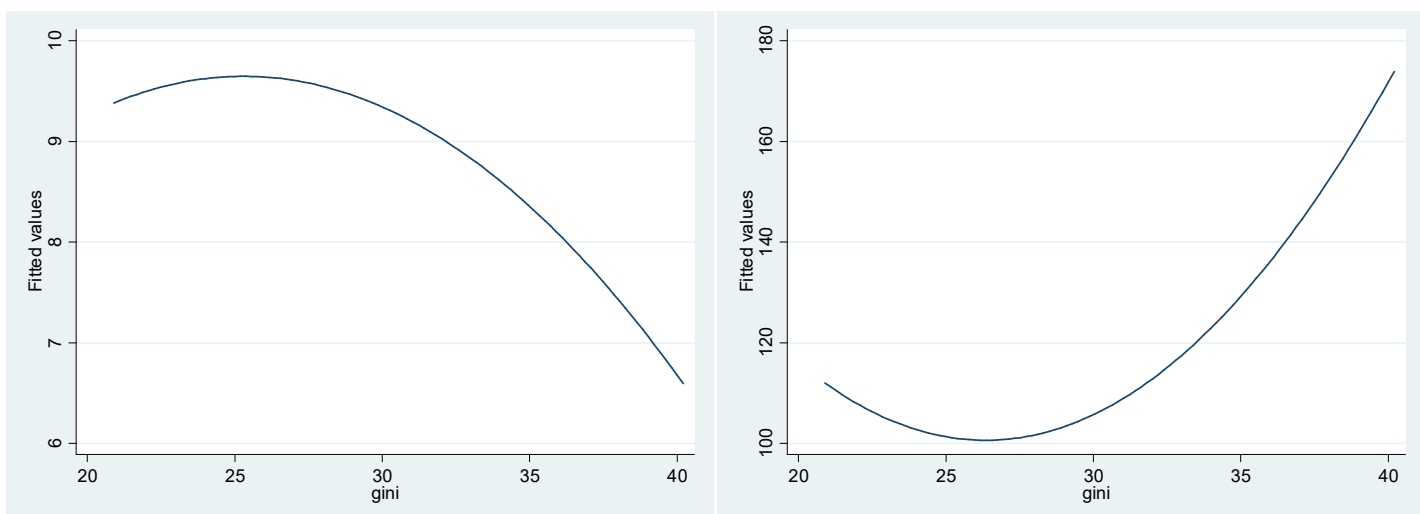

Figure 4. Estimates for relation Gini-GDP per capita (left figure), CO2-Gini (right figure) for EU13

Source: Author's calculations

\section{Conclusions}

Our analysis has shown that there is an inverted U-shape curve relationship between income inequality and carbon emissions for the two groups of EU countries, confirming that Gini index affects $\mathrm{CO} 2$ emissions in a non-linear manner. However, the sign of this relation is not the same for the two groups of EU countries, demonstrating that there are important differences between them. The sign of the coefficients in the two groups depend on the level of income per capita. In case of rich countries (EU15), lower Gini index is associated with reduced $\mathrm{CO} 2$ emissions and economic development. The group of less developed countries (EU13) still confront with problems related to reducing $\mathrm{CO} 2$ emissions and have higher income inequality.

We have presented important differences between the two groups of countries, EU15 and EU13, regarding the effect of GDP per capita on income inequality and carbon emissions. The reason for the fact that EU15 group of countries have lower Gini index and lower $\mathrm{CO} 2$ emissions can be due to the fact that rich countries have more resources to invest in clean energy and technologies in order to modernize industrial production. Usually more developed countries have a higher interest in ensuring a good-quality climate environment, as these countries are more preoccupied with environmental safety and wellbeing of their citizens.

Therefore, we can draw attention to the role of increasing income per capita, as a way to achieve lower income inequality, which is a necessary condition for ensuring the transition to zero-carbon emissions and to a green economy. We can also take into consideration redistribution policies in order to reduce income inequality, which can also play an important part in achieving the target of lowering carbon emissions.

The study of convergence between the two groups of countries, EU15 and EU13, can show when countries in the group of new member states in the European Union will reach the same level of economic development, and consequently, better performance in case of other economic indicators, specifically income inequality and carbon emissions. 
Climate change mitigation policies as well as the necessity to reduce carbon emissions and environmental degradation are strongly related to the objective to increase GDP per capita and also decrease income inequality.

\section{References}

Bae, J.H.: Impacts of Income Inequality on CO2 Emission under Different Climate Change Mitigation Policies. Korean Economic Review, Korean Economic Association, 34, 187-211 (2018).

Boyce, J.: Inequality as a Cause of Environmental Degradation. Ecological Economics. 11, 169-178 (1994).

Boyce, J.K.: Is inequality bad for the environment? Equity and the Environment, 15, 267- 288, Emerald Group Publishing Limited, Bingley, United Kingdom (2007).

Donadelli, M., Grüning, P., Jüppner, M., Kizys, R.: Global temperature, R\&D expenditure, and growth. SAFE Working Paper Series 188, Leibniz Institute for Financial Research SAFE (2017).

Drabo, A.: Impact of income inequality on health: Does environment quality matter? Environment and Planning A, 43(1), 146-165 (2011).

European Environment Agency: Climate change, impacts and vulnerability in Europe 2016. EEA report no. 1/2017: EEA, Copenhagen (2017).

Guo, L.: CO2 emissions and regional income disparity: Evidence from China. Singapore Economic Review, 59(01), 1-20 (2014).

Heerink, N., Mulater, A., Bulte, E.: Income inequality and the environment: Aggregation bias in environmental Kuznets curves. Ecological Economics, 38, 359-367 (2001).

International Labour Organization: World Employment Social Outlook 2018. Greening with jobs (2018).

Ivanova, D., Vita, G., Steen-Olsen, K., Stadler, K., Melo, P.C., Wood, R., Hertwich, E.G.: Mapping the carbon footprint of EU regions. Environ Res Lett 12(5):054013 (2017).

Knight, K.W., Schor, J.B., Jorgenson, A.K.: Wealth inequality and carbon emissions in high-income countries. Social Currents, 4(5), 403-412 (2017).

Kuznets, S.: Economic growth and income inequality. American Economic Review, March, 1-28 (1955).

Ravallion, M., Heil, M., Jalan, J.: Carbon emissions and income inequality. Oxford Economic papers $52,651-669$ (2000).

Scruggs, L.: Political and Economic Inequality and the Environment. Ecological Economics. 26, 259275 (1998). 